\title{
AN ANALYSIS OF REGIONAL DIVERSITY OF WOMEN EMPOWERMENT IN PUNJAB, PAKISTAN \\ Hafsah Batool ${ }^{1}$, Nabila Asghar ${ }^{2}$, Hafeez ur Rehman ${ }^{3 *}$ \\ ${ }^{1}$ Lecturer, Department of Economics, Lahore College for Women University, Lahore, Pakistan; ${ }^{2}$ Associate Professor, Department of Economics and Business Administration, University of Education Lahore, Pakistan; \\ ${ }^{3 *}$ Professor/Chairman, Department of Economics, School of Business and Economics, University of Management and Technology Lahore, Pakistan. \\ Email: 1batooleconomist@gmail.com, 2drnabeelakhan.eco@gmail.com, ${ }^{3 *}$ hafeez.rehman@umt.edu.pk \\ Article History: Received on $7^{\text {th }}$ June 2021, Revised on $19^{\text {th }}$ June 2021, Published on $25^{\text {th }}$ June 2021
}

\begin{abstract}
Purpose of the study: This study intends to demonstrate the importance of sub-provincial variation in women empowerment in Punjab, Pakistan.

Methodology: The study used the Cumulative Women Empowerment Index (CWEMI) for three regions of Punjab Pakistan, using primary data of 950 respondents. The data is obtained through multistage stratified cluster sampling techniques from Upper, Central, and Southern Punjab based on the prevalence of female literacy rate. The statistical technique namely Multivariate Analysis of Variance (MANOVA) and Analysis of Variance (ANOVA) has been used to make the comparison on a regional and dimensional basis.
\end{abstract}

Main Findings: The result of the study shows that there exits substantial sub-provincial variation in upper, central, and southern Punjab regarding different domains of women empowerment.

Applications of this study: This study identifies the regional diversity in women empowerment in Punjab, Pakistan. The results of the study provide guidelines to the policymakers in formulating appropriate policies for eliminating diversity in women empowerment in different regions of Punjab, Pakistan.

Novelty/Originality of this Study: Improvement in women empowerment is regarded as an essential human right and sustainable development goals that needs appropriate monitoring. The majority of previous studies have tried to measure women's empowerment through developing several indices but these indices appear insufficient to meet the international standards. The present study is an attempt to track multiple domains of women empowerment through CWEMI. The results of the study may bring up a status of women empowerment across different regions of Punjab, Pakistan.

Keywords: CWEMI, Multiple Domains, Multistage Stratified Cluster Sampling, Polychoric Principal Component Analysis, Sub-provincial Variation.

\section{INTRODUCTION}

Increasing women's empowerment is a major human right and development goal (Sen et al., 2014) but the process of women's empowerment fails to achieve targets set for Pakistan by the United Nations. Furthermore, the social values prevailing in Pakistan have emerged as a major hurdle in the way of women empowerment and existing social exclusion has affected the development process adversely in the country (Madni \& Shahzad, 2021). (Hirway \& Mahadevia, 1996; Klasen, 2006) are of opinion that the availability of proper information is another obstacle in the way of measuring women empowerment in developing counties. The experience of developed nations revealed that women's empowerment may help improve the quality of life (Tahir \& Majeed, 2021). An increase in women empowerment leads to reduce the infant and child mortality rate and also improves their health and nutrition (Fuchs et al., 2010). Moreover, an increase in education of women may reduce the misery of their lives particularly in developing countries (Psacharopoulos, 1994). The previous research on this topic revealed that women empowerment is a multidimensional concept and a single method fails to measure it properly. Several methods are available in literature such as Gender Development Index (GDI), Gender Empowerment Measure (GEM), and Gender Inequality Index (GII) to measure it but most of them have drawbacks that reduce their accuracy. The main focus of GDI and GEM was on gender gaps while GII focuses on the drawbacks of GDI and GEM. It includes both reproductive health care, and maternal and infant mortality rate. But this approach neglected the important aspects of personal security and decision-making by women.

The researchers and the policymakers have been trying to develop a method having minimum shortcomings. The World Economic Forum has presented an alternative index known as the Global Gender Gap Index (GGGI) for highlighting the gender gap in terms of achievements considering four important categories which include economic participation and opportunity, educational attainment, health and survival, and political empowerment (Papakonstantinou, 2019). The above-mentioned indices suffer from the drawbacks which bring up the need to assess the status of women through some alternative approaches. The problem with this index is that it is designed for comparison at the national level, ignoring within-country variations which are considered as essential for formulating appropriate policies for women empowerment.

For the last several decades the researchers have been trying to bring up various aspects of women empowerment in developing countries like Pakistan and to measure it properly. This indicates that the research work on women 
empowerment has received a lot of attention from researchers after the social development goals set for Pakistan. Several studies are available on the Pakistan economy which brings up several factors regarding the increase in women empowerment in Pakistan but these studies have used those methods which suffer from drawbacks. This indicates the need for measuring women's empowerment using an appropriate method. The present study is an attempt to measure women empowerment through Female Empowerment Index (FEMI) for upper, central, and southern Punjab, Pakistan which is based on 19 questions from Demographic and Health Surveys (DHS) for five years. The significance of FEMI is that it addresses the drawbacks and considers those aspects which were neglected by the previous methods. It brings up the true picture of regional diversity in women empowerment.

Women empowerment has not been given much emphasis particularly in backward and farfetched areas of Pakistan. Furthermore, due to prevailing conservative social values, women are not allowed to work outside their homes. The research work conducted on diversity in women empowerment in the context of Pakistan is scanty. The present study is an attempt to analyze the regional diversity of women empowerment in Punjab Pakistan. This study will provide a comparative analysis of diversity in women empowerment in three regions of Punjab Pakistan. It will help the policymaker to design appropriate policies for improving the role of women in the development process of Pakistan's economy.

\section{DATA AND METHODOLOGY}

\section{The data}

The present study uses primary data, which is obtained through the detailed questionnaire developed for the said purpose. The data were gathered through cluster sampling. The targeted respondents of this study are only married women between the age of 17 and 50 years, having a Mean of 32.84 and SD of 8.326. A multistage cluster sampling technique has been used for data collection. The total sample of 950 respondents is determined using the following statistical formula,

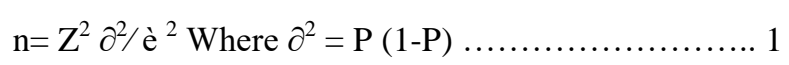

Where $\mathrm{P}$ shows the value of the prevalence rate (female literacy rate). The number of households obtained from urban and rural is in the proportion of 2017 census is $63 \%$ and $37 \%$ for urban and rural areas. Sample households are selected on the next stage from clusters based on the quotient rule with a random start. The detailed household lists of collections have been obtained from the Bureau of Statistics (BOS).

The problem under consideration is an exclusive effort to scrutinize the extent of women's empowerment in three zones of Punjab using a set of indicators with a solid theoretical background as dimensions. The existing studies explore women's empowerment in terms of the ability to make life and economic decisions, and mobility (Khalid et al., 2020), land rights (Allendorf, 2007), education, and decision-making power (Sridevi, 2005). Alkire et al. (2013) build on previous work to measure women's empowerment in agriculture using five dimensions: production, decision-making power, control over income use, leadership, and time allocation.

CWEI has been constructed by combining six dimensions, i.e., decisions making, socio-cultural mobility, familial/interpersonal empowerment, economic empowerment, political empowerment, and psychological empowerment, with 28 variables to get a comprehensive analysis of women empowerment. The description of selected dimensions for the current study is presented in Table 1.

Table 1: Selected dimensions of Women empowerment

\begin{tabular}{lll}
\hline & Dimension & Detail \\
\hline i & Household decision making (HHD) & $\begin{array}{l}\text { Women's involvement in ordinary and significant economic and } \\
\text { non-economic household decisions }\end{array}$ \\
\hline ii & Economic empowerment (EEM) & $\begin{array}{l}\text { Access to formal financial institutions, saving mechanism, and } \\
\text { control overuse of personal income }\end{array}$ \\
\hline iii & Social mobility (SEM) & Women freedom to visit various places \\
\hline iv & $\begin{array}{l}\text { Familial/interpersonal } \\
\text { (FAMEM) }\end{array}$ & $\begin{array}{l}\text { Various personal, child-related decisions and family planning } \\
\text { matters }\end{array}$ \\
\hline v & Political participation (POLEM) & Freedom to caste vote and participation in political activities \\
\hline vi & Psychological empowerment (PSYEM) & For this purpose, a generalized self-efficacy scale is used. \\
\hline
\end{tabular}

Statistical association of variables in each dimension has been checked through Kendall tau b rank correlation. The Polychoric Principal Component Analysis (PCA) with orthogonal varimax (Kaiser off), can be applied when all the variables are numeric, i.e. the variables are either quantitative or continuous, and the relationships among variables are linear (Gifi, 1990; Kamanou, Ward \& Havinga, 2005). The variables in our data set are categorical, measured at the ordinal and nominal level, so that classical PCA may not be the suitable technique because the ordinal variables do not have an origin or a unit of measurement. Therefore, variances and covariances have no sense in estimating the covariance (correlation) matrix; the standard PCA is no longer the appropriate technique. 
The retained six components summarise each dimension of women empowerment by extracting standard information captured by single indicators, avoiding redundancy, and minimizing statistical biases. A weighted sum of the components where weights are obtained by dividing loadings with the square root of eigenvalue, i.e., variance explained by each component in polychoric principal component analysis, has been considered the cumulative index of women empowerment in Punjab. The scores for each component are calculated by multiplying the variables with appropriate weights obtained through polychoric PCA.

$$
\mathrm{CWEI}=\mathrm{HHD}+\mathrm{SEM}+\mathrm{EEM}+\mathrm{POLEM}+\text { FAMEM }+ \text { PSYEM } \ldots \ldots \ldots \ldots \ldots . .2
$$

There are several socio-economic, demographic, and political characteristics of households that explain changes in women's empowerment. Therefore, the present study attempts to identify the critical determinants at the household level that play a significant role in women's empowerment.

\section{RESULTS AND DISCUSSIONS}

First of all this study discusses the regional disparity and variability of women empowerment from the perspective of the geographical distribution of Punjab. Table 2 presents the mean for different women empowerment dimensions, comparing the Upper, Southern, and Central Punjab situations.

Table 2: Regional Diversity and Variability of Women Empowerment in Upper, Southern, and Central Punjab

\begin{tabular}{lll}
\hline Dimension of women empowerment & Regions & Mean \pm S.E \\
\hline Psychological & Upper Punjab & $3.64 \pm 0.0304 \mathrm{~A}$ \\
Empowerment & Southern Punjab & $3.748 \pm 0.0284 \mathrm{~B}$ \\
& Central Punjab & $4.096 \pm 0.0341 \mathrm{C}$ \\
\hline Social Mobility & Upper Punjab & $2.39 \pm 0.0304 \mathrm{~A}$ \\
& Southern Punjab & $2.397 \pm 0.0284 \mathrm{~A}$ \\
& Central Punjab & $2.418 \pm 0.0341 \mathrm{~A}$ \\
\hline Household Decision Making & Southern Punjab & $1.998 \pm 0.0284 \mathrm{~A}$ \\
& Central Punjab & $3.505 \pm 0.0341 \mathrm{~B}$ \\
& Upper Punjab & $3.898 \pm 0.0304 \mathrm{C}$ \\
\hline Familial Empowerment & Southern Punjab & $0.705 \pm 0.0284 \mathrm{~A}$ \\
& Upper Punjab & $0.957 \pm 0.0304 \mathrm{~B}$ \\
& Central Punjab & $1.814 \pm 0.0341 \mathrm{C}$ \\
\hline Economic Empowerment & Upper Punjab & $0.223 \pm 0.0304 \mathrm{~A}$ \\
& Southern Punjab & $0.237 \pm 0.0341 \mathrm{~A}$ \\
& Central Punjab & $0.321 \pm 0.0341 \mathrm{~A}$ \\
\hline Political Empowerment & Upper Punjab & $0.216 \pm 0.0304 \mathrm{~A}$ \\
& Central Punjab & $0.366 \pm 0.0341 \mathrm{~B}$ \\
& Southern Punjab & $0.395 \pm 0.0284 \mathrm{~B}$ \\
\hline Confidence & \multicolumn{1}{c}{ used: } \\
P value adjustment: Tukey method for comparing a family of 3 estimates \\
significance level used: alpha $=0.05$ & & \\
\hline
\end{tabular}

Source: Author's Calculations

According to Siwal (2009), self-effectiveness, self-esteem, psychological health, collective understanding of inequality, capacity to travel, disposition and women's rights, and the general appreciation of the strength of women and inclusiveness are embodied in psychological empowerment. Psychological aspects include knowledge of women's human rights and their desire to deal with diverse household shocks. The findings show the average number of women in Central Punjab is higher (4.09) than in Southern Punjab (3.78) and High Punjab (3.64), on average. In addition, access to school, health care, work prospects are higher in central Punjab (Irfan et al., 2019).

The present study endorses social mobility as an essential feature of women's socio-cultural ability indicators (Bespinar, 2010). The experiments have been maintained in line with (Jejeebhoy \& Sathar 2001; Khan \& Maan, 2008). The average of 2.418 indicates that women are more socially mobile in Central Punjab as compared to Upper Punjab (2.39) and Southern Punjab (2.397) (for details, see Table 2). However, women's total social mobility rate is not substantially different in Upper, Central, and Southern Punjab.

Another essential feature of engagement and power-sharing among household members is the decision-making process in the families (Acharya et al., 2010). The role of women in the household decision-making process allows them to increase self-determination, bargaining capacity, resource management, self-esteem, self-reliance, prestige, domestic ability (Parveen \& Leonhäuser, 2005). Therefore, the expanded role of women in household decision-making goes far beyond inspiring them in other fields of life. In this regard, Upper and Southern Punjab closely follow women's role in household decision-making as in Central Punjab (for details, see Table 2). The fourth component of family empowerment relates partly to the social empowerment and resourcefulness that women bring to household matters 
(Haque et al., 2011). For family empowerment, similar results are found. The results also show that the Central Punjab women are more paternal (1.814) than Southern Punjab women (0.705) and Upper Punjab women (0.957) (for details, see Table 2).

A woman is motivated financially if she is willing to succeed and grow and has the authority to make decisions and take them into account (Golla et al., 2011). Mbeiza (2018) pointed out that economic equality strengthens women's position in the financial matter, decision-making, and power-sharing practices. Noureen et al. (2015) think that work and paying workers represent a crucial factor for economic empowerment. The previous research work on Punjab indicates that women from Central Punjab are more financially motivated due to their higher level of wellbeing, schooling, and employment opportunities. The standard of services in Central Punjab is better as compared to the southern and the upper regions. The results presented in Table 2 indicate that, on average, Central Punjab women $(0.321)$ are more economically empowered as compared to Southern women (0.237) and Upper Punjab women (0.223).

Political empowerment applies, within a political system, to awareness of the origins, sponsorship of the household for political engagement, right to vote, participation of women in indigenous political structures/movements, provision of 24 candidates or legislatures, in particular, representation in local government, representation of women in national and regional governments. The result of the study shows that women are more conscious of their political rights in Southern Punjab as women here are more motivated politically than women in Central and Upper Punjab.

Tukey's method in ANOVA has been used to create confidence intervals for all pairwise differences between factor level means of different dimensions of women empowerment in different regions. Different grouping like A, B, C indicate a significant difference in mean values while the same group like A, A, A indicates no significant difference in different dimensions of women empowerment in different parts of Punjab. The comparative analysis presented in Table 2 shows no significant variation in economic empowerment and social mobility dimensions of women empowerment, while in other dimensions, the situation is quite different in the three zones of Punjab.

Figure 1 shows that women residing in Central Punjab have more potential and are often driven in empowerment. This research concludes that in the sense of previous studies, women in central Punjab have more potential overall than previous studies.

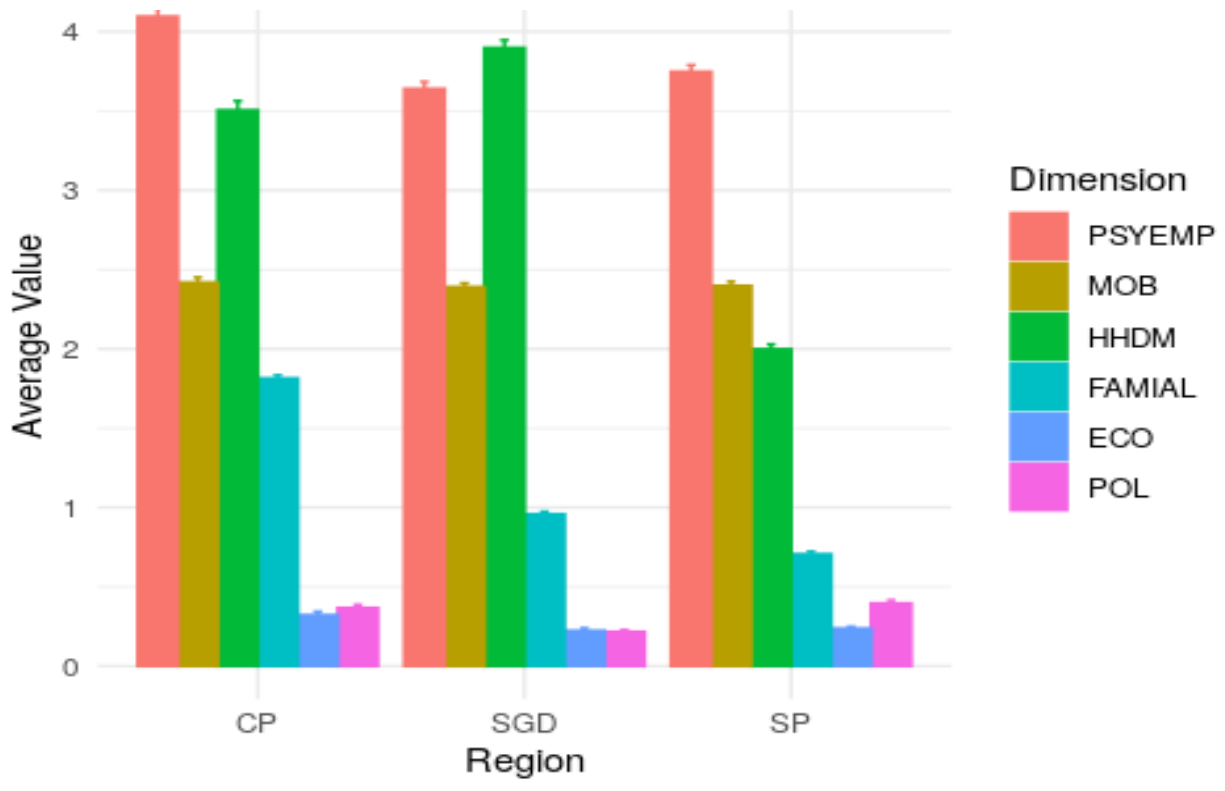

Figure 1: Variability in Each Dimension of Women Empowerment in three Zones of Punjab

A Multivariate Analysis of Variance (MANOVA) test has been carried out to observe the relevance of all variables in the advancement of women as a group, regardless of whether they vary considerably or not. In ANOVA, the statistical variations are verified by an unbiased grouping variable on one constant dependent variable while MANOVA develops this analysis into a weighted linear combination or cumulative variable, considering several continuous dependent variables. The newly formed mixture compares whether its distinct classes or levels of the separate variable vary.

The results of MANOVA is presented in Table 3. The p-value associated with the Pillai statistic is very small, which is a strong evidence that the mean vectors of the two dimensions are not the same in the districts.

Table 3: Multivariate Analysis of Women Empowerment in three Zones of Punjab

\begin{tabular}{llllll}
\hline & DF Pillai & Approximate F & NMDF & DENDF & Pr>F \\
\hline Regions & 21.2014 & 237.43 & 12 & 1886 & $<2.2 \mathrm{e}-16 * * *$ \\
\hline Residuals 947 & & & & \\
\hline
\end{tabular}




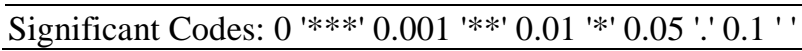

Source: Author's Calculation

The ANOVA test has been used to determine the relationship between the different key dimensions of women empowerment in selected districts of each zone. For applying ANOVA the total variance is split into two groups: between-group variance and within-group variance.

Table 4 also indicated a significant interaction between Districts and Women's Empowerment.

Table 4: ANOVA Results for Women Empowerment for Each Region

\begin{tabular}{|c|c|c|c|c|c|}
\hline Response & DF & SMSQ & MSQ & FV & Pr>F \\
\hline \multicolumn{6}{|c|}{ Psychological Empowerment (PSYEMP) } \\
\hline Region & 2 & 31.72 & 15.863 & 24.798 & $3.183 \mathrm{e}-11 * * *$ \\
\hline Residuals & 947 & 605.76 & 0.639 & & \\
\hline \multicolumn{6}{|c|}{ Social Mobility (MOB) } \\
\hline Region & 2 & 0.116 & 0.059 & 0.2392 & 0.7873 \\
\hline Residuals & 947 & 229.22 & 0.242 & & \\
\hline \multicolumn{6}{|c|}{ Familial Empowerment (FAMIAL) } \\
\hline Region & 2 & 195.092 & 97.546 & 998.99 & $<2.2 \mathrm{e}-16 * * *$ \\
\hline Residuals & 947 & 92.469 & 0.098 & & \\
\hline \multicolumn{6}{|c|}{ Household Decision Making (HHDM) } \\
\hline Region & 2 & 695.15 & 347.58 & 544.48 & $<2.2 \mathrm{e}-16 * * *$ \\
\hline Residuals & 947 & 604.53 & 0.639 & & \\
\hline \multicolumn{6}{|c|}{ Political Empowerment (POL) } \\
\hline Region & 2 & 6.108 & 3.054 & 31.375 & $6.407 \mathrm{e}-14 * * *$ \\
\hline Residuals & 947 & 92.187 & 0.098 & & \\
\hline \multicolumn{6}{|c|}{ Economic Empowerment (ECO) } \\
\hline Region & 2 & 1.589 & 0.794 & 9.902 & $5.546 \mathrm{e}-05 * * *$ \\
\hline Residuals & 947 & 75.987 & 0.081 & & \\
\hline \multicolumn{6}{|c|}{ Significant. Codes: 0 '***' 0.001 '**' 0.01 '*' 0.05 '.' 0.1 ' ' 1} \\
\hline \multicolumn{6}{|c|}{$\begin{array}{lc}\text { SMSQ = Sum of square } & \text { DF }=\text { Degree of freedom } \\
\text { MSQ = Mean square } & F V=F \text { value }\end{array}$} \\
\hline
\end{tabular}

Source: Author's Calculation

The results presented in Table 4 reveal the existence of a significant interaction between Districts, and Women's Empowerment.

The p-value is $<0.001$ for psychological empowerment, which means a significant difference exists between the overall Psychological Empowerment in Southern, Central, and Northern Punjab. Similar results are also found for Familial empowerment, Household decision-making, political empowerment, and economic empowerment. While in the social mobility, the p-value is 0.7873 , which shows no significant difference between social mobility in the Southern, Central, and Northern Punjab. It indicates that there exists variation in another dimension of women empowerment in all the regions of Punjab.

Table 5: ANOVA for Regions and Women Empowerment with interaction

\begin{tabular}{|c|c|c|c|c|c|}
\hline & DF & SMSQ & MSQ & FV & $\operatorname{Pr}(>\mathbf{F})$ \\
\hline Districts & 2 & 246 & 123.1 & 411.5 & $<2 \mathrm{e}-16^{* * *}$ \\
\hline Dimension & 5 & 10457 & 2091.4 & 6989.5 & $<2 \mathrm{e}-16^{* * *}$ \\
\hline DIST: Dimension & 10 & 684 & 68.4 & 228.4 & $<2 \mathrm{e}-16^{* * * *}$ \\
\hline Residuals & 5682 & 1700 & 0.3 & & \\
\hline \multicolumn{6}{|c|}{ Significant. codes: 0 '***' $0.0011^{\prime * * '} 0.011^{\prime * \prime} 0.05$ " 0.1 " 1} \\
\hline \multicolumn{6}{|c|}{$\begin{array}{lc}\mathrm{SMSQ}=\text { Sum of square } & \mathrm{DF}=\text { Degree of freedom } \\
\mathrm{MSQ}=\text { Mean square } & \mathrm{FV}=\mathrm{F} \text { value } \\
\end{array}$} \\
\hline
\end{tabular}

Source: Author's Calculation

Table 5 shows a significant interaction between districts and dimensions of women empowerment. The results show if the dimension is fixed, then there is significant variation in different districts, and if districts are fixed, there is significant interaction in the perspective of different dimensions of women empowerment. 


\section{CONCLUSION}

The prior research work on examining female empowerment was exclusively at the national level. The results of the present study reveal that the country has substantial regional variation across multiple aspects of women's empowerment, illustrating the regional variations in addition to national variation. The study highlights not only the significance of subnational reporting of women empowerment but also the national measures. For this purpose, it is demonstrated that women's empowerment is much lower in the Upper and Southern of Punjab than in Central Punjab. In education, decision-making, and access to prenatal care, the situation in Upper Punjab is worsened even it is better in Southern Punjab. In categories in which both Upper and Southern Punjab show improvement, but Upper Punjab still lagged significantly behind. The targeted interventions is needed to improve women's empowerment in both the Upper and Southern Punjab. All women in Punjab have shown different levels of psychological empowerment, economic empowerment, and familial empowerment. There is no significant difference between social mobility in the Southern, Central, and Upper Punjab. It indicates that there is variation in other dimensions of women empowerment in all the regions of Punjab, but the restriction level in social mobility for women in all the areas of Punjab is still the same.

The women who live in Central Punjab enjoy more psychological, interpersonal, and economic empowerment than the women of other zones of Punjab. In the family decision-making process, women in upper Punjab are empowered more while women in Southern Punjab are politically more empowered. Women in this zone enjoy better life as they have more opportunities for education, health, employment, and decision-making power. This reveals the existence of regional diversity of women empowerment in three regions of Punjab, Pakistan. The policy to reduce the regional diversity of women empowerment may be an appropriate step towards paying the way for sustainable development in Punjab. From the above discussion, it is concluded that empowering and developing women may serve as a potential development strategy to achieve SDG by 2030.

Due to the paucity of time and resources, the present study is confined to Punjab province only. The present research work can be extended to other provinces of Pakistan. For this purpose, the CWEMI can be readily computed for other provinces of the country, and its ability to track spatial variation in women empowerment across a broad set of categories. It may make it more useful than existing approaches, especially for in-depth effective policy intervention. Future researchers can extend their work using FEMI to bring up the clear and true picture of diversity in women empowerment across all provinces of Pakistan.

\section{THE IMPLICATION OF THE STUDY}

The major objective of this study is to address the problems of regional diversity in women empowerment which is an essential part of sustainable development goals set for Pakistan. The results of the study will help the policymakers in formulating appropriate policies for the developing countries like Pakistan.

\section{ACKNOWLEDGEMENT}

The authors are thankful to their colleagues for their encouragement in conducting this study. The author appreciates their comments given at different stages of this study.

\section{AUTHORS' CONTRIBUTION}

Hafsa Batool conceptualized the present idea and conducted empirical work. The work on the theoretical framework was done by Hafeez ur Rehman. Nabila Asghar verified the analytical methods and supervised the empirical analysis and helped in writing the discussion of results and conclusion.

\section{REFERENCES}

1. Acharya, D. R., Bell, J. S., Simkhada, P., Van Teijlingen, E. R., \& Regmi, P. R. (2010). Women's autonomy in household decision-making: a demographic study in Nepal. Reproductive health, 7(1), 1-12. https://doi.org/10. 1186/1742-4755-7-15

2. Alkire, S., Meinzen-Dick, R., Peterman, A., Quisumbing, A., Seymour, G., \& Vaz, A. (2013). The women's empowerment in agriculture index. World development, 52, 71-91. https://doi.org/10.1016/j.worlddev.201 $\underline{3.06 .007}$

3. Allendorf, K. (2007). Do women's land rights promote empowerment and child health in Nepal? World development, 35(11), 1975-1988. https://doi.org/10.1016/j.worlddev.2006.12.005

4. Beşpınar, F. U. (2010, November). Questioning agency and empowerment: Women's work-related strategies and social class in urban Turkey. In Women's studies international forum (Vol. 33, No. 6, pp. 523-532). Pergamon. https://doi.org/10.1016/j.wsif.2010.09.003

5. Beteta, H. C. (2006). What is missing in measures of women's empowerment? Journal of human development, 7(2), 221-241. https://doi.org/10.1080/14649880600768553

6. Burroway, R. (2015). Women's rights save lives: a cross-national analysis of infant and child mortality and Women's access to land, property, and loans in developing countries. Sociology of Development, 1(4), 418-441. https://doi.org/10.1525/sod.2015.1.4.418 
7. Fuchs, R., Pamuk, E., \& Lutz, W. (2010). Education or wealth: which matters more for reducing child mortality in developing countries? Vienna Yearbook of Population Research, 175-199. https://doi.org/10.1553/populat ionyearbook2010s175

8. Ewerling, F., Lynch, J. W., Victora, C. G., van Eerdewijk, A., Tyszler, M., \& Barros, A. J. (2017). The SWPER index for women's empowerment in Africa: Development and validation of an index based on survey data. The Lancet Global Health, 5(9), e916-e923. https://doi.org/10.1016/S2214-109X(17)30292-9

9. Gates, M. F. (2014). Putting women and girls at the center of development. Science, 345(6202), 1273-1275. https://doi.org/10.1126/science.1258882

10. Gaye, A., Klugman, J., Kovacevic, M., Twigg, S., \& Zambrano, E. (2010). Measuring key disparities in human development: The gender inequality index. Human development research paper, 46, 1-37.

11. Gifi, A. (1990). Nonlinear multivariate analysis. Wiley-Blackwell.

12. Golla, A. M., Malhotra, A., Nanda, P., \& Mehra, R. (2011). Understanding and Measuring Women's Economic Empowerment: Definition. Framework and Indicators. Washington, DC.

13. Haque, M., Islam, T. M., Tareque, M. I., \& Mostofa, M. (2011). Women empowerment or autonomy: A comparative view in Bangladesh context. Bangladesh e-journal of Sociology, 8(2), 17-30.

14. Hirway, I., \& Mahadevia, D. (1996). Critique of Gender Development Index: Towards an Alternative Economic and Political Weekly, 31(43), WS87-WS96.

15. Irfan, M. S., Gill, Y. Q., Ullah, S., Naeem, M. T., Saeed, F., \& Hashmi, M. (2019). Polyaniline-NBR blends by in situ polymerization: application as stretchable strain sensors. Smart Materials and Structures, 28(9), 095024. https://doi.org/10.1088/1361-665X/ab1df3

16. Jejeebhoy, S.J., \& Sathar, S.J. (2004). Women's autonomy in India and Pakistan: The influence of religion and region. Population and Development Review, 27(4), 687-712 https://doi.org/10.1111/j.1728-4457.2001.00687.x

17. Kamanou, G., Ward, M., \& Havinga, I. (2005). Statistical issues in measuring poverty from non-survey sources. Draft of Chapter 5 of Handbook of Poverty Statistics: Concepts, Methods and Policy Use. United Nations Statistics Division.

18. Khan, T. M., \& Maan, A.A. (2008). Socio-cultural milieu of women's empowerment in district Faisalabad. Pak. Journal of Agriculture Sciences, 45(3), 78-90. follow APA

19. Khalid, M. W., Samargandi, N., Shah, A. H., \& Almandeel, S. (2020). Socio-Economic Factors and Women's Empowerment: Evidence from Punjab, Pakistan. International Economic Journal,34(1), 144-168. https://doi.org/10.1080/10168737.2019.1677742

20. Klasen, S. (2006). UNDP's gender-related measures: Some conceptual problems and possible solutions. Journal of Human Development, 7(2), 243-274. https://doi.org/10.1080/14649880600768595

21. Madni, G., \& Shahzad, K. (2021). Evaluating the Spectacle of Social Exclusion in Pakistan. Empirical Economic Review, Forthcoming. Retrieved from https://ojs.umt.edu.pk/index.php/eer/article/view/296

22. Mbeiza, L. (2018). The Effect of Micro-Credit on Women Empowerment in Uganda: The Case of BRAC. MS Economic Policy and Planning Thesis at Makerere University College of Business and Management Sciences, Uganda follow APA

23. Noureen, I., Zubair, M., Bhatti, A. A., \& Abbas, G. (2015). Shear-free condition and dynamical instability in $\mathrm{f}$ (R, T) gravity. The European Physical Journal C, 75(7), 1-8. https://doi.org/10.1140/epjc/s10052-015-3547-x

24. Parveen, S., \& Leonhäuser, I. U. (2005). Empowerment of rural women in Bangladesh: A household level analysis, Margraf. https://www.tropentag.de2004/abstracts/full/382.pdf

25. Papakonstantinou, V. (2019). 2019 World Economic Forum Annual Meeting, Davos, Switzerland: Report on infrastructure sessions. Journal of Mega Infrastructure \& Sustainable Development, 1(1), 104-107.

26. Psacharopoulos, G. (1994) Returns to investment in education: a global update. World Development, 22, 13251343 https://doi.org/10.1016/0305-750X(94)90007-8

27. Sen, G., \& Mukherjee, A. (2014). No empowerment without rights, no rights without politics: Gender-equality, MDGs and the post-2015 development agenda. Journal of Human Development and Capabilities, 15(2-3), 188202. https://doi.org/10.1080/19452829.2014.884057

28. Sridevi, T. O. (2005). Empowerment of Women-A systematic analysis. India Development Foundation IDF Discussion Paper.

29. Siwal, B. R. (2009). Gender framework analysis of empowerment of women: A case study of Kudumbashree programme. National Institute of Public Cooperation and Child Development New Dehli India. https://doi.org/10.2139/ssrn.1334478

30. Tahir, T., \& Majeed, M. (2021). An Empirical Analysis of the Relationship between International Trade and Quality of Life. Empirical Economic Review, Forthcoming. https://ojs.umt.edu.pk/index.php/eer/ article/view/799

31. Women, U. N. (2016). Our mission. UN Women. http://also-chicago.org/also_site/wp-content/uploads/2016/ 04/Impact-of-VAWA-Grantee-Data-PPT.pdf 